\title{
LOX IMVI
}

National Cancer Institute

\section{Source}

National Cancer Institute. LOX IMVI. NCI Thesaurus. Code C117181.

A melanoma cell line established from a lymph node metastasis from a 58 year old male patient with cutaneous melanoma. 